\title{
Family Law, Involuntarily Separated Couples and their Property
}

\author{
Robyn Carroll
}

This article considers the implications for parties to a marriage and their property when they are forced to separate as a result of ill health. This has particular relevance for elderly Australians who experience declining health accompanied by cognitive decline and loss of decisionmaking capacity. The potential for the property interests of the couples in these circumstances, to be altered by family law proceedings, has been confirmed by the High Court of Australia in Stanford $v$ Stanford. The door to the Family Court is open for financial proceedings to be brought on behalf of a party to a marriage who no longer has the capacity to make financial decisions for him or herself and who has financial needs that cannot be met from their own property. The article examines the legal position of couples when third parties are contemplating the commencement of proceedings in the Family Court for financial orders.

\section{INTRODUCTION}

This article concerns a family situation that will occur with increasing frequency in an ageing population. This is the situation where a couple has not chosen to end their marriage but are physically separated due to accommodation and care needs arising from ill health of one or both parties. In an ageing population with an increased life expectancy and a growing number of people suffering the debilitating effects of dementia and other causes of cognitive decline, 'involuntary' and 'forced' separation in this sense is increasingly common. ${ }^{1}$

In these circumstances a child of a party to the marriage, or another third party, might consider it to be in the best interests of one party to the marriage to seek financial orders against the other party, for maintenance or property settlement. This is a significant step, not the least because of the final nature of a property settlement order made under s 79 of the Family Law Act 1975 (Cth) (the Act). It may require the sale of the family home and the division of assets, ${ }^{2}$ including sale of the home in which the other spouse is living. ${ }^{3}$ The issues that arise in these circumstances are not confined to cases where the parties to the marriage have had to physically separate involuntarily of course. Even when parties to a

$1 \quad$ Ultimately the question whether a couple have separated and whether a party to the marriage has the capacity to make decisions about where they live and about their marriage and financial affairs are matters of jurisdictional fact. What constitutes 'separation' for purposes of family law is discussed in Part III below. See, eg, Conti v Conti (2008) 221 FLR 42.

3 See recently, eg, Granath and Granat [2014] FCWA 49, [71]. 
marriage have separated one of them might lose the capacity to commence proceedings on their own behalf and their circumstances, including their care needs, may necessitate a property settlement. In cases where the parties have not chosen to separate, however, the significance of these issues is magnified because a third party is taking a legal action that has implications for the marriage relationship, as well as the financial situation of the respondent spouse.

Although the family law courts ${ }^{4}$ have jurisdiction to make property orders for parties to a marriage, the argument has been made on more than one occasion that these orders should only be made for parties whose marriage has broken down. ${ }^{5}$ While a marriage is intact, there is an expectation that the parties will make financial provision for each another. It has been assumed that a court will usually find it is not just and equitable to make an order altering the property interest of the parties to the marriage if they are still living together as husband and wife. This assumption is based on 'the injustice that might result if there is subsequently a breakdown of the parties' marriage' because at this time a totally different property order might be appropriate ${ }^{6}$ More recently, it has been argued that to do so is inconsistent with s 43 of the Act which states that one of the principles to be upheld by the Family Court is 'to preserve and protect the institution of marriage'. ${ }^{7}$

Ideally couples will plan in advance for financial decision-making in the event that they lose decision-making capacity, and expressly anticipate how their assets are to be used to support their care and accommodation needs in the future. Many couples may choose not to do this, relying instead on trust and an expectation that their spouse and family will 'do the right thing' by them. Others may simply overlook the benefits of making provision for the future needs of both parties in advance. Many people would not have anticipated that a home of modest value owned by one party and brought into a marriage would dramatically rise in value in recent decades in some Australian housing markets and become an asset worth many times the value of other assets of their spouse. Where there is a disparity of wealth between spouses, and the spouse with less assets has financial needs that arguably are unmet by their spouse, the possibility of a property settlement to meet those needs may arise. This scenario is reflected in the facts of the High Court of Australia case Stanford $v$ Stanford (Stanford). ${ }^{8}$ This case, and the implications of the decision for families and family law practitioners, are the subject of this article.

4 The term Family Court is used here to refer generally to Australian family law courts exercising jurisdiction under the Family Law Act 1975 (Cth), namely the Family Court of Australia, the Federal Circuit Court of Australia, the Family Court of Western Australia and the Magistrates Court of Western Australia.

$5 \quad$ See Part IV below.

$6 \quad$ Anthony Dickey QC, Family Law (6th ed, 2014) 591.

$7 \quad$ Family Law Act 1975 (Cth) s 43(1)(a). This was one of the arguments by the respondent husband made in the case of Stanford $v$ Stanford (2012) 247 CLR 108, discussed in Part V. 
The article focuses on the financial issues arising in family law for married couples because, as explained in Part V, the jurisdiction of the Family Court to make financial orders for couples who have not separated does not arise for couples in de facto relationships. ${ }^{9}$ This does not diminish the fact that the same issues, tensions and stresses identified in this article arise for couples in a de facto relationship. Where a couple are not married, there may be a greater likelihood that children and other third parties will treat the spouses' assets as separate upon physical separation, notwithstanding a history of common use of property by the couple.

Part II of the article provides a brief overview of the types of family law issues that are relevant to ageing Australians. Part III considers what it means for a couple to 'separate' for purposes of family law and the implications of loss of mental capacity to separate for the purposes of divorce. Part IV sets out the facts and decision in Stanford and earlier cases where similar issues of involuntary separation arose. Part V sets out the law as stated in Stanford and the implications of the decision in the light of subsequently decided cases. Part VI summarises the current legal position and points to matters requiring further consideration. It is argued that there is a delicate balance to be struck between preserving the institution of marriage and protecting a party to a marriage who has lost the capacity to make decisions about their marriage and their financial affairs. It concludes that the decision in Stanford has made an important contribution to ensuring this delicate balance can be observed. While there are not likely to be many circumstances in which it will be just and equitable for the Family Court to make orders for the division of property of parties to an intact marriage, the ability of the Court to make such orders ensures that the financial needs of a party to an intact marriage can be addressed if necessary.

\section{BACKGround: FAmily LAW Issues For Ageing Australians}

Given modern rates of marriage and divorce and the formation of de facto relationships, older Australians' lives will more frequently be affected by family law. Even if a couple's own relationship endures, they are likely to experience marriage or relationship breakdown, family conflict and parenting issues involving their children, grandchildren and stepchildren, other family members or friends. An example of where the law

9 This point is discussed in greater detail in Part VI. The implications of the reasoning in Stanford for couples to de facto relationships deserves more detailed consideration than this article, which focuses on the legal significance of marriage, aims to provide. In particular, for a couple living in a 'de facto relationship' as defined in s $4 \mathrm{AA}$ of the Act, the question whether their relationship continues after they have physically separated or has been terminated is relevant not only to whether it would be just and equitable in the circumstances to make a property settlement order under s $90 \mathrm{SM}(3)$, but also to the question whether the court has jurisdiction to make any orders at all pursuant to Pt VIIIAB of the Act. 
has responded to calls for recognition by older Australians is the express recognition of the reality that grandparents frequently play an important role in the lives of children. ${ }^{10}$ Grandparents are often called upon to take on a carer role for their grandchildren, with obvious lifestyle and financial consequences. ${ }^{11}$ Other areas of family law are equally applicable to the aged, including divorce, property division and spousal maintenance.

Living longer can increase the chances that the parties to a marriage will interact with family law. They might remarry or re-partner after a divorce or the death of their spouse. It can also increase the chance that children will become concerned about decisions made by their parents and, in some cases, by their parent's spouse. Assets may have been accumulated or brought into a marriage and, with this, expectations may have arisen in the children of the parties to a marriage as to who will inherit those assets. Family and succession lawyers are familiar with the need to prepare wills that anticipate these expectations and with the legal proceedings that can eventuate when they are not met. The potential for conflict between new spouses or partners and children of previous relationships over financial entitlements can arise at any time in the course of the subsequent relationship. These conflicts may relate to concerns by family members about financial deprivation or neglect of an elderly parent by a new partner or spouse. They may also reflect concerns about the preservation of family assets more than an interest in an elderly parent's lifestyle choice and the benefit to their parent of a new relationship.

There is no age limit to entering into a marriage, or to separation and divorce. ${ }^{12}$ The same can be said about forming and ending de facto relationships. Living longer, however, can also increase the chance that a party to a marriage will lose legal capacity to make important financial and lifestyle decisions for himself or herself as a result of cognitive decline. Important decisions may need to be made at some stage about the sale of assets, residential accommodation and the payment of a bond and fees to a

$10 \quad$ Family Law Act 1975 (Cth) s 65C(ba).

11 The ABS reports that in 2002 there were 22,500 Australian families in which grandparents were the sole carers of their grandchildren (involving 31,100 children aged 0-17 years). Grandparents also make a considerable contribution to child care. In 2002, almost one in five (19 per cent) children spent some time in the care of a grandparent in the survey reference week, and grandparents provided around a third (31 per cent) of the total hours of child care in that week: ABS, Australian Social Trends, 4102.0 (2005).

12 The median age at divorce in 2012 for females was 41.8 and for males 44.6 . The median age at divorce has generally been increasing for both males and females over the past 20 years: ABS, Marriages and Divorces, 3310.0 (2012). It has been suggested that the rise in the median age at divorce may be attributed to the increasing age at marriage, the increase in the interval between marriage and divorce, and reflective of the overall ageing of the Australian population: ABS, Divorces, 3307.0.55.001 (2007). The ABS data shows that 1.7 per 1000 males and 0.7 per 1000 females over the age of 65 were divorced in 2012 . These figures are consistent with the figures reported in recent years and indicate a rise in the divorce rate in this age bracket since 1993: ABS, Marriages and Divorces, 3310.0 (2012). 
residential facility. In these circumstances, aside from where an enduring appointment of an attorney or a guardian has been created, the role of decision-maker usually will be assumed informally by their spouse and major decisions concerning living arrangements and health case made by the spouse or other family members. Sometimes, it will be necessary to make a formal appointment of the spouse, or a family member other than the spouse, to make decisions for the incapable spouse. ${ }^{13}$ Where there is no family member or no other person who is willing and suitable for appointment, a public body can be appointed. ${ }^{14}$

There are various circumstances in which a child or other third party to a marriage might want to bring proceedings in the Family Court on behalf of a party to a marriage who has lost their legal capacity for lifestyle and financial decision-making. One circumstance is where it is argued that a person did not have the requisite capacity to enter into the marriage and that the marriage should be decreed void. Another circumstance is where a divorce application is made on behalf of party to a marriage. As we will see in the next Part, the latter application will only be successful when there is clear evidence that the spouse, on whose behalf the proceeding is commenced, formed the requisite intention to separate when they had capacity to make that decision. Otherwise, the marriage can only be brought to an end by the other party to the marriage, assuming they have the requisite capacity to decide to separate and take the necessary action to do so. The third circumstance, and the focus of this article, is where a third party to the marriage seeks to bring financial proceedings on behalf of an incapable spouse against the other party to the marriage.

There is nothing novel in the involvement of children and other third parties on behalf of a person who is unable to conduct legal proceedings on their own behalf. Rules of court provide for proceedings to be commenced by a next friend in civil proceedings and, in the Family Court, by a case guardian. ${ }^{15}$ It is not uncommon for a third party to the marriage to bring proceedings on behalf of a person who is unable by reason of a mental or physical incapacity to conduct parenting, financial or other proceedings on their own behalf. What is uncommon is the involvement of third parties in financial proceedings under the Act between parties to an intact marriage.

13 Formal appointment of a decision-maker for an adult with decision-making incapacity is available by legislation in each State and Territory: Powers of Attorney Act 2006 (ACT), Powers of Attorney Act 2003 (NSW), Powers of Attorney Act (NT), Powers of Attorney Act 1998 (Qld), Powers of Attorney and Agency Act 1984 (SA), Powers of Attorney Act 2000 (Tas), Instruments Act 1958 (Vic), Guardianship and Administration Act 1990 (WA).

14 In Western Australia, for example, pursuant to the Guardianship and Administration Act 1990 (WA), the State Administrative Tribunal can appoint the Public Advocate as a guardian or administrator of last resort (s 44(5), s 68(5)) and the Public Trustee as an administrator (s 68).

15 Family Law Rules 2004 (Cth) Pt 6.3. The person seeking to be appointed as case guardian may also, but need not necessarily, have been appointed as a formal decision-maker by an enduring instrument or by order of a State or Territory board or tribunal. 
The fact that a party to a marriage who has diminished decisionmaking capacity may find himself or herself reliant on another person to make important decisions about their care, accommodation, and financial support gives rise to concerns about the potential for financial neglect of that person by family members. The scenario is ripe for allegation and counter allegation of financial abuse and exploitation. This article identifies two ways that concerns about financial abuse can arise when it is argued by a third party to a marriage that, notwithstanding that the marriage is intact, the financial needs of a person who lacks capacity to bring family law proceedings on their own behalf are not being met. Firstly, from the respondent spouse's point of view, the argument might be heard that the third party is seeking to achieve a property settlement to bolster the estate of the incapable person with the inheritance expectations of their successors in mind. Second, from the third party's point of view, the argument might be heard that the respondent spouse is neglecting the financial needs of their spouse and denying their spouse the benefits of the property that has been acquired, conserved or accumulated during the marriage. Both of these arguments arose in Stanford.$^{16}$ Both point to the need for family lawyers and the Family Court to be alive to the potential for financial abuse of vulnerable adults and knowledgeable of ways that the law can provide protection.

One way that a party to a marriage who has capacity to decide to end their marriage relationship can address financial abuse by their spouse is to separate from their spouse and seek a property settlement. This is not an option for a person who has lost the capacity to form the requisite intention. The next Part of the article addresses what it means for a couple to 'separate' for purposes of family law and the implications of loss of mental capacity to separate for the purposes of divorce.

\section{Separation And Divorce}

Divorce is only available in Australia upon proof that the parties to a marriage have 'separated and thereafter lived separately and apart for a continuous period of not less than 12 months'. ${ }^{17}$ 'Separation' for the purpose of making a divorce order establishes the breakdown of the marital relationship. The law is clear that for the purposes of divorce, separation involves more than physical separation. The fact that a husband and wife choose or need to live apart on a temporary or permanent basis is not sufficient to constitute separation.

The Full Court of the Family Court has held: ${ }^{18}$

$16 \quad$ (2012) 247 CLR 108.

$17 \quad$ Family Law Act 1975 (Cth) s 48(2).

18 In Marriage of Pavey (1976) 10 ALR 259, 261-262, approving this passage, with two minor amendments, from the judgment of Watson $\mathrm{J}$ in In Marriage of Todd (No 2) (1976) 9 ALR 401, 403. This passage is also referred to with approval by the Full Court in In Marriage of Falk (1977) 15 ALR 189, 195-196. 
Separation means more than physical separation - it involves the breakdown of the marital relationship (the consortium vitae). Separation can only occur in the sense used by the Act where one or other of the spouses form the intention to sever or not to resume the marital relationship and act on that intention, or alternatively act as if the marital relationship has been severed. What comprises the marital relationship for each couple will vary. Marriage involves many elements some or all of which may be present in a particular marriage - elements such as dwelling under the same roof, sexual intercourse, mutual society and protection, recognition of the existence of the marriage by both spouses in public and private relationships, and the nurture and support of the children of the marriage.

Clearly, there must be an intention by one or both of the parties to sever their marital relationship, and that intention must be communicated in some way to the other party and acted upon. ${ }^{19}$ These requirements apply equally to a party to a marriage who has lost their mental capacity to form the intention to separate. ${ }^{20}$

Not surprisingly, when a party to a marriage is forced by ill health to stay in hospital or to live in residential care, this does not mean he or she has 'separated' from their marriage partner, even if there is no likelihood or expectation that the couple will ever live together again and there are many changes to the way they share their married life. Physical separation alone does not constitute breakdown of the marital relationship. Couples who live apart some or a lot of the time by choice, for example for work opportunities such as fly in-fly out work arrangements, have not 'separated'. When one party to a marriage is incarcerated, that fact does not alone signify that the parties have separated..$^{21}$ There are many factors that a court will consider as evidence that the marriage has broken down. The withdrawal or refusal to provide financial support by one spouse to another spouse may or may not be significant, depending on how the parties conducted the marriage before the alleged separation and what assets and income they can access individually.

Family Court financial proceedings are usually brought between parties who have separated and no longer live as a couple. There is no requirement in the Act that parties be divorced or even separated for any length of time before commencing property proceedings. ${ }^{22}$ The deci-

19 In Marriage of Pavey (1976) 10 ALR 259, 262.

20 Price v Underwood (Divorce Appeal) (2009) 41 Fam LR 614, [145]; Margaret Otlowski, 'Recent Cases' (2010) 1 Family Law Review 46. See also In Marriage of $D$ (2001) 27 Fam LR 736 (where an application by the trustee for the applicant husband was refused on the basis that the husband lacked capacity to form the intention to separate at the time the application was filed), and McKenzie (by her litigation guardian Ms D) v McKenzie [2013] FCCA 1013 (where the court was satisfied that the wife had capacity to manifest her desire to separate from her husband at the time of physical separation and her subsequent loss of capacity as a result of hypoxic brain injury did not prevent the requirements of $\mathrm{s} 48$ of the Act being satisfied).

21 In Marriage of Whiteoak (1980) FLC $₫ 90-837$.

22 Since 1983, property proceedings arising out of the marital relationship can be brought pre-divorce or post-divorce and are not confined to being brought as ancillary proceedings to principal relief such as divorce or nullity. This was effected 
sion to separate need not be made jointly and they can be held to have separated notwithstanding that their cohabitation was brought to an end by the action or conduct of only one of the parties. ${ }^{23}$ It is enough if one of the parties forms the intention to separate and acts in a way that communicates their intention to sever the marriage relationship to the other party. As will be explained in Part V, in these circumstances a court will generally conclude that it is just and equitable to make a property settlement order of some sort pursuant to s 79(1) of the Act. The extent to which the legal entitlements to property are adjusted between the parties will be determined in accordance with s 79(4) by taking into account the parties' contributions to their joint and individual property, their future needs and a number of other factors. ${ }^{24}$ As a general proposition the longer the marriage, the more likely it is that the parties' contributions will be assessed as equal. There is, however, no presumption that contributions have been equal or that the property should be divided equally. ${ }^{25}$

\section{Stanford, Involuntarily Separated Couples and Financial Proceedings in the Family Court}

The case of Stanford, as the Full Court of the Family Court noted, raised a question which is particularly relevant to contemporary Australian society, namely: ${ }^{26}$

Whether and if so in what circumstances, the Court should make an order for property settlement pursuant to s 79 of the Family Law Act 1975 (Cth) ("the Act") where a marriage is still intact but where a physical separation has been forced upon the parties by reason of one of the parties' health.

This is not the first case in which this question has arisen. The question whether the parties to a marriage had separated, and the legal significance of finding that they had not, was an issue in Jennings (by his next friend State Trustees Ltd) $v$ Jennings ${ }^{27}$ (Jennings) and Sterling $v$ Sterling and Protective Commissioner, ${ }^{28}$ cases cited and referred to by the Family Court in the Stanford decisions. There are a number of similarities between the facts of these cases and Stanford. In each case the parties to the marriage were physically separated by the ill health of one of the parties who required residential accommodation or hospitalisation. In each case the parties had lived together as a married couple for a long time and there was no evidence that either party had formed the intention to sever the marital relationship. The judgments in these cases are indicative of

by the amendment of the definition of 'matrimonial cause' in s 4(1)(ca) of the Act by the Family Law Amendment Act 1983 (Cth).

23 Family Law Act 1975 (Cth) s 49(1).

24 See Family Law Act 1975 (Cth) s 79(4).

25 In Marriage of Mallet (1984) 156 CLR 605, 610 (Gibbs CJ), 625 (Mason J), 639 (Deane J), 647 (Dawson J).

26 Stanford v Stanford (2012) 47 Fam LR 105, [2].

27 (1997) 22 Fam LR 510.

28 [2000] FamCA 1150. 
the differing views of a s 79 application brought in respect of parties who are living separately where neither party has decided to sever the marital relationship.

In Jennings, Dessau J determined not to proceed to consider an application made to the Court by the husband by his next friend (the State Trustees Ltd), on the basis that: ${ }^{29}$

[T] here is nothing to be gained by embarking upon a full property application in the circumstances of the parties who have formed no intent to separate; where one is suffering illness and is hospitalised and where the other continues to visit and partake in his care to the extent to which she is able. Orders finally determining the property issues between them could not be appropriate, fair or just in that context.

In Sterling, the separation had been brought about by the need for the wife to be institutionalised for the rest of her life as a result of her having Alzheimer's disease. At first instance, Moss J concluded that it would be just and equitable to make a property order on an application by the Protective Commissioner for the State of New South Wales acting as the wife's next friend. ${ }^{30}$ His Honour assessed the parties' contributions to be equal and made a 10 per cent adjustment in the husband's favour for s 75(2) factors. In view of the property settlement, Moss J dismissed the application for spouse maintenance. An appeal to the Full Court was unsuccessful. ${ }^{31}$ By majority, the Full Court upheld the decision of Moss J. Special leave to appeal to the High Court was granted in this case but the matter was settled before the appeal was heard. ${ }^{32}$

One member of the Full Court of the Family Court, Kay J, dissented. His Honour expresses in his judgment a number of concerns about the implications of the court exercising jurisdiction to make property orders in these circumstances. As to the significance of an intact marriage, his Honour says:

It seems to me that marriage is not seen to be an institution that is entered into during such time as the health of the parties enables them to live together. The existence of the necessity for the parties to live in separate premises, brought about by the deterioration in the health of one or both of the parties, ought not be seen, of itself, as an appropriate trigger for the persons managing the affairs of one or other of the parties to successfully apply to have an order made under s 79. In my view, if a court is invited to resist the making of such an order, there ought be proper reasons elucidated as to why the court is intending to make an order in circumstances where it will provide no clear benefit to the party in whose name the order is sought. An order made in the course of a subsisting marriage may be

29 Jennings (by his next friend State Trustees Ltd) $v$ Jennings (1997) 22 Fam LR $510,517$.

$30 \quad$ Sterling and Sterling [1999] FamCA 1676.

31 Sterling $v$ Sterling and Protective Commissioner [2000] FamCA 1150.

32 Sterling \& Sterling \& Protective Commissioner (2001) 22(16) Leg Rep SL4 HCA. Reference is made to the fate of the special leave application in Re S by her Case Guardian $R$ and $S$ by his Case Guardian $S$ [2010] FCWAM 15, [11], and in transcript of the special leave application in Stanford $v$ Stanford [2012] HCATrans 154. 
a clear indication that the court is not willing to protect the institution of marriage as a union entered into for life. ${ }^{33}$

Concerns about interference by property orders in the arrangements of a married couple are not confined to couples who have not separated. In some cases the evidence will not be sufficient to support a finding that the marriage has broken down. This was the situation in Conti and Conti (Conti)..$^{34}$ In this case the court was particularly concerned because the respondent wife had failed to respond to the applicant husband's litigation guardian and trustee's application for orders for sale of the home in which the wife was living and division of their assets. Contrast the outcome in Starkey $v$ Starkey (No 2) ${ }^{35}$ (Starkey), where Murphy J expressed the sentiment that 'it is profoundly sad' that the court was dealing with contested proceedings in respect of settlement of property at the end of a 40 year marriage. ${ }^{36}$ In Starkey, the respondent wife's submission was that notwithstanding that the husband had been in a nursing home for a considerable time, the marriage had not broken down. Her submission was unsuccessful, based on the facts of the case. ${ }^{37}$

The time was ripe after Jennings and Sterling for a case to arise in which the questions about whether, and in what circumstances, property orders should be made between parties to an intact marriage to be revisited by the Family Court and, ultimately, the High Court. That case arose in Western Australia in 2010. The case concerns a married couple, $\mathrm{Mr}$ and Mr Stanford ${ }^{38}$ who married in 1971. It was the second marriage for both of them. At the time of the Family Court proceedings the couple were in their mid-80s. For 37 years the parties lived in the former matrimonial home of Mr Stanford (the husband) and his first wife at an inner suburb of Perth. The property was purchased by the husband and his first wife in February 1962 and when they divorced the home was transferred to the husband's sole name. Mrs Stanford (the wife) divorced her first husband in 1968. In December 1968 she won $\$ 16,000$ on Lotto and used the majority of her winnings to pay out the mortgages on her home in a southern suburb of Perth. Subsequently, the wife sold her home to one of her daughters and her daughter's husband. The husband and wife both retired in 1989 on pensions from the Department of Veteran's Affairs.

In March 1995 the husband made a will. He did not discuss the will with his wife. He explained by letter dated 27 March 1995 to his wife and his sons that as the wife intended to leave her estate to her daughters, excluding the husband, he provided for the wife to have a life tenancy in their home and for his estate to be divided equally between his sons or their children. The husband further explained that he was certain the

33 Sterling $v$ Sterling and Protective Commissioner [2000] FamCA 1150, [33].

34 [2008] FMCAfam 1156.

35 (2009) 41 Fam LR 517.

36 Ibid, [12].

37 Ibid, [41].

38 This is not the parties' actual name. The Family Court anonymises published judgments. 
wife's daughters would have no expectations of him, just as his sons would have no expectations from the wife. The wife was unaware of this letter. On 1 September 2005 the wife signed an Enduring Power of Attorney in favour of her daughters. The husband was not aware of this.

In 2008 the wife suffered a stroke. She was unable to return to live at home with her husband and she was placed in an aged care facility. The wife was also suffering from dementia. In 2009 the husband had a fall and was hospitalised but he later returned to the home where he continued to live with his son as his carer. The wife's daughters sought sufficient funds from the husband to pay a large bond for an aged care facility which they believed was more suitable for the wife than the facility in which she was placed after she was discharged from hospital. The husband did not agree that the change to his wife's accommodation was appropriate and refused to raise the bond against his house. After no satisfactory financial agreement was reached between the husband and the daughters on the wife's behalf, one of the daughters commenced proceedings in the Family Court as case guardian for the wife. The husband was represented by his son as case guardian due to the difficulty the husband would have conducting the litigation on his own behalf. The husband's case was that although he and his wife were physically separated, they were still in a marital relationship. He continued to provide for the wife and placed $\$ 40,000$ into an account for her use. He visited her three times a week at the aged care facility.

The wife's case was that the Family Court could, and should in this case, make orders for a division of property under s 79(1) of the Act. The husband's case was that no orders should be made in favour of the wife. His reasoning was twofold. First, it was argued that the Family Court does not have power to make orders with respect to the property of parties to an intact marriage and therefore it cannot make the orders sought by the wife. This is a jurisdictional issue. Second, that even if the court has jurisdiction to make orders in these circumstances, it should not make any orders when the parties are married and the marriage has not broken down. In these circumstances, it was argued, it would not be just and equitable to make such orders. It was also argued that no orders were needed as funds were available to the wife and, as the wife was now in a high care facility, the substantial amount sought on the wife's behalf for a bond was no longer required.

The application by Mrs Stanford was successful at first instance in the Family Court of Western Australia before Magistrate Duncanson (as she then was). ${ }^{39}$ Consistent with earlier authorities, including Jennings, her Honour held the Court had jurisdiction to hear and determine the matter based on the fact that these were proceedings relating to property 'arising out of the marital relationship' and a 'matrimonial cause' within the meaning of $\mathrm{s} 4(1)(\mathrm{ca})(\mathrm{i})$ of the Act. This determination was upheld by the Full Court and there was no challenge to her Honour's finding on

$39 \quad$ Re S by her Case Guardian R and S by his Case Guardian S [2010] FCWAM 26. 
appeal. ${ }^{40}$ The Full Court referred for support to High Court decisions in Dougherty $v$ Doughert ${ }^{41}$ and Fisher $v$ Fisher ${ }^{42}$ and the appellate Family Court decision in Kapoor $v$ Kapoor (Kapoor). ${ }^{43}$

As to the second issue, her Honour determined that orders should be made. The husband was ordered to pay the sum of $\$ 612,931$ to the wife within 60 days. This amount was calculated by application of the principles in s 79(4) of the Act. The Magistrate ascertained the assets of the parties and determined that the overall percentage each should receive based on their contributions was 57.5 per cent to the husband and 42.5 per cent to the wife. Significant to this conclusion were the length of the marriage and the contributions of each party, albeit different, to the marriage. An appeal by the husband to the Full Court was successful and on October 2011 the Full Court set aside the orders made by the Magistrate. In doing so, the Full Court upheld the Magistrate's decision that the Family Court had jurisdiction to make property orders in respect of a married couple who had not separated.

The Full Court held that her Honour erred because she did not give adequate reasons as to why she thought that the orders she made were just and equitable. In particular, inadequate reasons were given as to why it was necessary to make final property orders given the effect on the husband of requiring him to sell his home of 48 years, the potential effect on the husband of the wife predeceasing him and the ability to adjourn the proceedings without prejudice to any continuation of the proceedings at a later time. Further, her Honour had not given adequate reasons as to why an order for periodic maintenance was not appropriate. ${ }^{44}$

The Full Court expressed the view that if the justice and equity of the case so required, interim orders, orders for periodic maintenance and an order to adjourn the proceedings ought to have been considered rather than a determination on a final basis. In the Court's view, it was open in this case for the wife to seek orders for periodic maintenance. After the appeal was allowed however, and before the Full Court had re-exercised its discretion to make final orders, the wife died. The Full Court applied s 79(8) of the Act which makes provision for the Court to make orders for a property settlement after the death of a party to the proceedings. On 19 January 2012 the Full Court ordered the husband to pay the sum of $\$ 612,931$ to the wife's personal representative upon the death of the husband or at such earlier time as may be determined by the case guardian. ${ }^{45}$ In other words, the husband was ordered to settle property on the wife's estate but only upon his death or at an earlier time such as when he sold his home. The Court did not expressly address the question why if the wife had not died it would have been just and equitable to make the

$40 \quad$ Stanford $v$ Stanford (2011) 46 Fam LR 240.

41 (1987) 163 CLR 278.

$42 \quad$ (1986) 161 CLR 438.

43 [2010] FamCAFC 113, [67]-[68] (Finn J).

44 Stanford v Stanford (2011) 46 Fam LR 240, [119].

45 Stanford $v$ Stanford (2012) 47 Fam LR 105. 
orders it did, given its conclusion that the wife's needs could be met in ways other than by a final property order.

The husband appealed the decision of the Full Court and the High Court granted special leave. The High Court unanimously allowed the appeal and set aside the orders of the Full Court. ${ }^{46}$ The High Court held that the legislative requirements of s 79(8) of the Act had not been satisfied because it had not been shown that, had the wife not died, it would have been just and equitable to make an order with respect to property. ${ }^{47}$ It followed that after her death it could not be found, as required by the Act, to be 'still appropriate to make an order with respect to property'. ${ }^{48}$ The High Court concluded that it had not been shown that the wife's needs during her lifetime were not being met (before her death). In this circumstance, given the absence of any expressed wish of the wife to alter the property interests of the party during her lifetime and in view of the impact on the husband of an order that his house be sold, it was not appropriate for the court to make a final order for a property settlement. ${ }^{49}$

What does the decision in Stanford mean for ageing Australians and the wealth they have accumulated during their lifetime? The decision confirms that maintenance and property orders can be made under the Act between parties to a marriage who have been separated involuntarily by ill health and other circumstances, as well as where the parties have separated intentionally. This invites potential applications by third parties, for example, by children, appointed guardians or administrators and other appointed substitute decision-makers. A significant decision in each case, however, will be whether it is just and equitable to make a s 79 order. The following Parts set out the legal requirements to be satisfied in order for a court to make a property order, and factors likely to be significant where the parties to the marriage have not made a decision to end their marital relationship.

\section{Property Orders and the 'Just and Equitable' REQUIREMENT}

Section 79(2) stipulates that a court:

[S] hall not make an order under this section unless it is satisfied that, in all the circumstances, it is just and equitable to make the order. ${ }^{50}$

This is an overriding consideration. ${ }^{51}$ The Full Court of the Family Court has previously recognised that $\mathrm{s} 79(2)$ is the mandatory legislative imperative (to reach a conclusion that is just and equitable) that drives

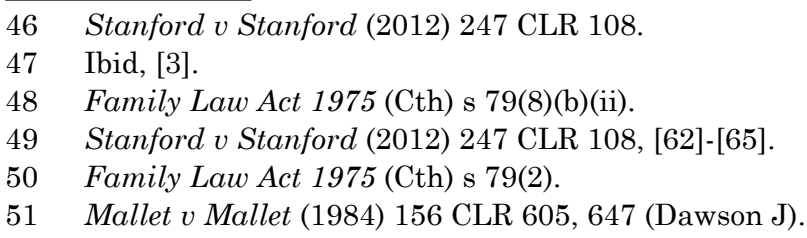


the ultimate result'. ${ }^{52}$ The High Court in Stanford importantly held that the language of s 79(2) requires a court to be satisfied, not just that the orders it proposes to make are just and equitable, but that it is just and equitable to make any order (emphasis added) with respect to the property of the parties to the marriage. ${ }^{53}$ Since the High Court decision in Stanford, the Full Court of the Family Court has reiterated that a court is required to be satisfied in every case that it is just and equitable to make an order pursuant to s 79(1) of the Act. ${ }^{54}$ This Part sets out the fundamental propositions identified by the High Court which inform the just and equitable requirement, circumstances in which the just and equitable requirement is likely to be met and some factors that may be significant to a court's decision. ${ }^{55}$

\section{A The 'Just and Equitable' Requirement and Three Fundamental Propositions}

The plurality of the High Court in Stanford identify the expression 'just and equitable' as a 'qualitative description of a conclusion reached after examination of a range of potentially competing considerations ${ }^{56}$ that 'does not admit of exhaustive definition'. ${ }^{57}$ It is not possible to 'chart its metes and bounds'. ${ }^{58}$ In exercising the power, however, the following three propositions must not be obscured..$^{59}$ First, it is necessary to begin consideration of whether it is just and equitable to make a property settlement order by identifying the existing legal and equitable interests of the parties in the property. Secondly, the broad power under s 79

52 See, eg, Norman and Norman [2010] FamCAFC 66 at [60].

53 (2012) 247 CLR 108, [49].

54 See, eg, Bevan v Bevan (2013) 49 Fam LR 387, [70]; Chapman v Chapman [2014] FamCAFC 91, [9], [27].

55 For further analysis of the implications of the High Court decision in Stanford see Patrick Parkinson AM, 'Family property law and the three fundamental propositions in Stanford v Stanford' (2013) 3 Family Law Review 80. See also Jacky Campbell, Stanford - The High Court Decision <http://www.fortefamilylawyers. com.au/site/DefaultSite/filesystem/documents/2012/225212.PDF>. Interestingly, Campbell, writing soon after the Stanford decision was handed down, questions whether '[p]erhaps the High Court was saying that the overriding requirement is not s 79(2), but s 79(1), which requires that the order be "appropriate"?' Given that Mrs Stanford died during the course of proceedings the applicable provision in her case was s 79(8), which also requires that the court make such orders 'as it considers appropriate'. The requirement of 'appropriate' orders has not attracted the same judicial attention as the requirement that a court be satisfied that making any order would be just and equitable. Arguably this can be explained on the basis that the appropriateness inquiry is addressed in applying the overriding requirement that a court also consider whether the orders it proposes to make are 'just and equitable' as the 'overriding requirement' in making orders under s 79 .

56 (2012) 247 CLR 108, 120.

57 Ibid, citing Gibbs CJ in Mallet v Mallet (1984) 156 CLR 605, 608.

58 Ibid, 120.

59 Ibid, 120, 122. 
is not to be exercised according to an unguided judicial discretion. The decision whether to make an order is not to be answered by assuming that the parties' rights to, or interests in, the property should be altered. Thirdly, whether it is just and equitable to make a property settlement order is not to be answered by assuming that one or other party has the right to have the property divided between them, or has a right to an interest in the property by reference to the various matters set out in s 79(4), which includes financial and non-financial contributions to property and to the welfare of the family. To make an order only because of the various considerations in s 79(4) is 'to conflate the statutory requirements and ignore the principles laid down by the Act' ${ }^{60}$ The plurality conclude that adherence to these propositions recognises the 'need to preserve and protect the institution of marriage' identified in s 43(1)(a) as a principle to be applied by courts in exercising jurisdiction under the Act. ${ }^{61}$

\section{B Circumstances in Which it Will be Just and Equitable to Make a Property Order}

The High Court recognises that in many cases the s 79(2) requirement will be readily satisfied by the choice of one or both of the parties to sever the marital relationship as this ends the common use of the property of the parties to the marriage. ${ }^{62}$ 'By contrast, the bare fact of separation, when involuntary, does not show that it is just and equitable to make a property settlement order. ${ }^{63}$ Where the marriage has not broken down other circumstances will be needed to justify the order. It is not inevitable when there has been only a physical separation that there will be a property settlement. In these circumstances the common use of assets may continue, for example by payment of an accommodation bond and fees. It can be assumed in these circumstances that the parties can agree to any necessary or desirable alteration of their property interests. Importantly for the purposes of this article the Court states:

[I]f one of the parties has become incompetent it is not to be assumed that the other party lacks the will and ability to make those necessary or desirable adjustments. ${ }^{64}$

The plurality recognise that there may be circumstances other than a voluntary separation signifying the end of the marital relationship in which a court may be satisfied that it is just and equitable to make a property settlement order. The example of where one party has unmet needs that cannot be met by a maintenance order is provided. Their Honours refer to this as only one possible circumstance that could justify an order and contemplate that there may be circumstances other than need that

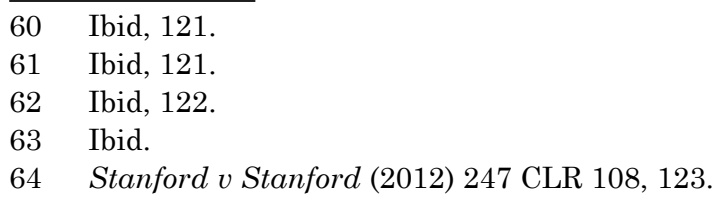


will satisfy s 79(2). Although the Court does not provide other examples, it is possible to imagine that a couple separated by a lengthy period of incarceration might not want to end their marriage but for one of them to need a partial or full property settlement.

\section{Approach to be Taken to Determine Whether Just and Equitable to Make Any Order and What Order to Make}

Before Stanford the Family Court and family law practitioners typically followed a 'four-step' approach. The Full Court has held on a number of occasions the 'four-step' approach to property settlement applications accepted in earlier decisions of the court provides a convenient way to structure both submissions and judgments. ${ }^{65}$ The 'four-step' approach, approved in In Marriage of Hickey ${ }^{66}$ (Hickey), envisaged:

Firstly, the Court should make findings as to the identity and value of the property, liabilities and financial resources of the parties at the date of the hearing. Secondly, the Court should identify and assess the contributions of the parties within the meaning of ss. 79(4)(a), (b) and (c) and determine the contribution based entitlements of the parties expressed as a percentage of the net value of the property of the parties. Thirdly, the Court should identify and assess the relevant matters referred to in ss 79(4)(d), (e), (f) and (g), ("the other factors") including, because of s 79(4)(e), the matters referred to in s 75(2) so far as they are relevant and determine the adjustment (if any) that should be made to the contribution based entitlements of the parties established at step two. Fourthly, the Court should consider the effect of those findings and determination and resolve what order is just and equitable in all the circumstances of the case.

Since the decision in Stanford, the Full Court of the Family Court has revisited the question how a court is to apply s 79 of the Act. The Full Court has acknowledged that the steps identified in Hickey provide a useful guide but has confirmed that the overriding consideration of whether it is just and equitable to make any order must be addressed. Provided this consideration is not overlooked, there is no hard and fast path that a court must follow to properly apply s 79.67 The notion that the 'just and equitable' requirement in s 79(2) is a 'threshold issue' has been firmly rejected. ${ }^{68}$ So has any suggestion that there is a prescribed pathway of decision-making or a mandatory requirement that $\mathrm{s} 79(4)$ matters be addressed when answering the question whether it would be just and equitable to make any order. ${ }^{69}$ The court has a wide discretion under s 79(2) which can include, but does not require consideration of, s 79(4) factors in making that determination. In Scott and Danton ${ }^{70}$ the

65 Bevan and Bevan (2013) 49 Fam LR 387, [60].

66 (2003) 30 Fam LR 355, [39].

67 Bevan v Bevan (2013) 49 Fam LR 387, [84].

68 Ibid, [86].

69 Chapman and Chapman [2014] FamCAFC 91, [9].

70 [2014] FamCAFC 203, [43]. 
Full Court agreed with a differently constituted Full Court in Chapman and Chapman ${ }^{71}$ that:

Section 79 demands a consideration, separately, of all of its requirements without conflation. Provided a trial judge has done so, and the reasons demonstrate that this has been done, no error is demonstrated by a failure to follow a particular order in doing so. Further, the breadth and depth of the consideration of the $\mathrm{s} 79(2)$ issue, and the extent of an adequate exposition of it in the reasons, will vary from case to case.

In summary, a trial judge must identify the property interests of the parties and determine whether the case before it is one in which it is just and equitable to make orders altering the property interests of the parties. If it is so satisfied, the court is to determine what those orders should be by reference to $\mathrm{s} 79(2)$ and the considerations in $\mathrm{s} 79(4)$. With this judicial guidance in mind, the next inquiry in this Part is to identify the factors that may be relevant to the decision to make a property settlement order in any particular case. The focus here is on cases where the parties have been involuntarily separated by their care and accommodation needs. ${ }^{72}$

\section{Just and Equitable Orders and Couples Who Have not Separated}

The High Court has made it clear that the decision whether it is just and equitable to make orders for the division of property is not to be based on any assumed entitlement resulting from contributions to the property, or to the welfare of the family pursuant to s 79(4) and statutory considerations in s 75(2) of the Act. As family law specialist and commentator Jacky Campbell points out, it is likely to be some time before conclusions can be drawn as to when making an order under s 79(1) will be just and equitable because the facts of the reported cases to date in which parties have sought orders where the couple have not separated are fairly distinctive. ${ }^{73}$ The cases are also few in numbers. In what follows, five factors of potential significance are identified and discussed.

\section{Financial Needs of the Applicant Spouse}

It is clear from the decision in Stanford that financial need is an important consideration in determining whether it is just and equitable to make an

71 [2014] FamCAFC 91, [19].

72 The question whether it is just and equitable to make any orders can also be a live issue for the court in cases where the parties have separated. See, eg, Watson (on behalf of the estate of Watson) $v$ Ling (2013) 49 Fam LR 303; Bevan $v$ Bevan (2013) 49 Fam LR 387; Fielding $v$ Nichol [2014] FCWA 77. The significant factors in these and subsequent cases may provide some assistance to courts making determinations in future cases where the parties have not separated.

73 Jacky Campbell, 'Property Settlement Orders When Parties are Not Separated or Are Involuntarily Separated' (2013) 23(3) Australian Family Lawyer 18, 28. In this article, Campbell reviews the facts and decision in a number of reported cases decided before Stanford and suggests the likely outcome of the case if the same facts were to arise today. 
order pursuant to s 79(1). Had Mrs Stanford not died before proceedings were concluded, and had there been an ongoing need for a bond to be paid for her aged care accommodation that could not have been met out of assets other than the property owned by Mr Stanford, the outcome of the case is likely to have been very different. In Cont $i,{ }^{74}$ the need for the husband's administrator to pay an accommodation bond for the nursing home in which he was living was a significant factor in the court's decision to make orders for the division of the couple's assets.

\section{Impact of the Order on the Parties to the Marriage}

The Full Court of the Family Court and the High Court make it clear that the needs of both parties, and the impact of an order finally altering the interests of the parties in their property, is a significant factor in determining whether a final property settlement order will be just and equitable as between parties to an intact marriage. This is clear from the following passage from the Full Court decision in Stanford:

In considering what was just and equitable under s 79 and s 75(2) the Magistrate was required to consider the effect of these orders on the husband and the fact that this was an intact marriage. Other than the forced separation of the parties by virtue of the wife being in a nursing home, the husband wished to remain in the home which had been the parties' home for in excess of 35 years, until such time as he could not reasonably remain there. ${ }^{75}$

3 Whether Orders Other Than Final Property Orders Will Meet the Needs of the Parties

The Full Court and the High Court in Stanford refer to the need to consider the ability of a maintenance order to meet the needs of a party to the marriage. This does not mean that the court has a general discretion under s 79 to decide whether to make a final property order (my emphasis). When an application is before the court, the court is bound to make a determination on the application. ${ }^{76}$ It may be the case however, that a final property order is not the only way to meet the immediate financial needs of a party to the marriage whose needs are not being met by their spouse.

Orders for spousal maintenance can be made between parties who have not separated. ${ }^{77}$ This is illustrated by the case In Marriage of Eliades, ${ }^{78}$ where a husband stopped giving his wife housekeeping money and instead purchased food himself. The wife was successful in her application to the Family Court for a maintenance order, payable by the husband to her bank account for household expenses for herself and the

74 [2008] FMCAfam 1156, [87].

75 (2011) 46 Fam LR 240, [112].

76 In Marriage of Neale (1991) 14 Fam LR 861.

77 Proceedings between the parties to a marriage for maintenance of one of the parties to the marriage is defined as a 'matrimonial cause' in s 4(1) of the Act. 
family. The ability of a financial administrator appointed as case guardian for a party to a marriage to obtain an order for maintenance is particularly important in cases where a party to a marriage has health care and accommodation needs that their spouse is unable or unwilling to recognise. ${ }^{79}$ A maintenance order will be of value in a case where a couple has not unequivocally separated, and where the evidence does not establish a need for the incapable spouse to have access to substantial funds, to live in an aged care facility for example. In this way, concerns that final property orders would be an unjustified interference with the marital relationship can be addressed by a finding that it is not just and equitable to make an order under s 79(1) where a maintenance order will suffice.

Another way that financial provision can be made for a party to a marriage that is still intact is by a partial property order under $\mathrm{s} 79(1)$. This is an order by which the interests of the parties in some of the property are altered, sometimes pursuant to interim orders, leaving the final determination of how the parties' property is to be divided to be decided on a future occasion. While the Family Court is not inclined to make a partial property order because it prefers to exercise the power under $\mathrm{s} 79(1)$ just once, ${ }^{80}$ the Court is prepared to do so in appropriate circumstances. ${ }^{81}$ The power of the Court to make a partial order warrants close and careful analysis for cases involving parties to an intact marriage because of the potential it provides for the court to balance the needs of the parties to the marriage against the impact of the order on the marital relationship.

The Living Arrangements of the Parties and Whether the Marriage has Broken Down

The s 79(2) requirement that it is 'just and equitable' to make a property settlement order clearly is not dependent upon a finding that the parties have separated voluntarily and the marriage has broken down. What then is the significance of the existing state of marital affairs in any particular case? Where a couple maintain their marital relationship, notwithstanding the move by one of them to a residential facility, for example by visits, it may be incumbent on the case guardian for the applicant spouse to make the case for orders on the basis of financial need. If the facts of Jennings and Stanford were repeated, one can expect that an application for a final property order would be refused on the basis that it would not be just and equitable to alter the parties' interests in their property.

There are a number of cases in which the courts have refused to make s 79 orders where the parties to the marriage have no intention of separating. For example, the courts have refused a property settlement order where the purpose of the application is to minimise their exposure

79 For an example of the circumstances in which this can arise see $N$ and $N$ [2006] WASAT 267.

80 Dickey, above n 6, 547.

81 Strahan and Strahan (Interim Property Orders) (2011) FLC ๆ93-466. 
to taxes. ${ }^{82}$ These cases show that a court will look at the marital relationship to which the parties' application relates to determine whether it is appropriate to make a property order at all. ${ }^{83}$ At the same time, Polik and Polik ${ }^{84}$ suggests that the court will look carefully at the motives behind a property application where it is suggested that the $\mathrm{s} 79$ proceedings are being brought for an improper purpose. In Polik, the parties had not yet separated, and although it was conceded that the marriage was under stress, both parties had strong religious convictions and neither party wished to apply for a divorce. The husband sought an order for a settlement of the parties' property and assets. The wife sought to have the husband's application dismissed, alleging that the husband's purpose of bringing the application was improper, namely to obtain a final order now so as to keep out of her reach any additional property to which she might be entitled at a later time. The court refused to strike out or grant a stay of $\mathrm{s} 79$ proceedings as an abuse of process, although it did not rule out the possibility that such a finding could be the subject of findings at a trial.

These and other atypical circumstances aside, one can expect that a court will usually conclude that it is just and equitable to make a s 79 order once it is satisfied that the parties have separated. In some cases, however, evidence of the parties' intention to separate may be contested, equivocal or absent. In such cases the court can, but does not need to, make a finding that there has been separation before it can make an order. In Kapoor ${ }^{85}$ the court regarded it as sufficient that the husband had applied for, and continued to press for, a property settlement, notwithstanding the wife's objections. In Starkey, ${ }^{86}$ Murphy J considered it to be 'a significant piece of evidence in the somewhat murky facts of this case' that the applicant husband (now acting by his case guardian) had commenced proceedings for a property settlement when he had full legal capacity. The respondent wife submitted that the marriage was not over and pointed to the fact that she continued to visit her husband in hospital. His Honour concluded that this evidence was 'neutral' so far as it pointed to a breakdown of the marriage and observed:

It is, to me at least, unsurprising that after a marriage of 40 years that a marriage might have broken down but yet the parties to the marriage

$82 \quad$ McCormack and Peakes [2009] FMCAfam 1250; Redman and Redman [2013] FamCAFC 183.

83 Similarly, use by parties to an intact marriage of the provisions of Pt VIIIAB to take unintended financial advantage of binding financial agreements, as revealed in ASIC $v$ Rich and Rich (2003) 31 Fam LR 667, has been precluded by legislation introduced after that case was decided.

84 [2012] FamCA 335. O'Reilly J considered that the husband was entitled to run his case and have the court then consider whether to exercise its discretion to make an order in his favour or to dismiss his application, at [108].

85 [2010] FamCAFC 113, [75] (Finn J).

86 (2009) 41 Fam LR 517, [29] (Murphy J). There was other evidence in this case that convinced his Honour that he ought to make orders in this case, see [31] and [42]. 
maintain some form of contact particularly in the circumstances where, as I have said, the husband is now incapacitated and in a nursing home. ${ }^{87}$

As seen above, even when there is an absence of evidence that the parties have separated, as in Conti, ${ }^{88}$ the court can conclude that it is just and equitable to make a property settlement order. In this case, the court was placed in the 'invidious situation' of determining whether and what orders to make in the face of the wife's unwillingness to take part in the proceedings. ${ }^{89}$ The circumstances were that the applicant husband was unable to pay his accommodation bond to the residential care facility where he was living without an order for the sale of the family home and a division of assets. ${ }^{90}$

\section{The Testamentary Intentions of the Parties to the Marriage}

The courts are well aware that the context for a property application may be 'an internecine war' between various members of the family. ${ }^{91}$ The potential for proceedings to be used to anticipate the succession plans of the parties to a marriage when one or both of the parties to the marriage has lost capacity to separate, to commence property proceedings in the Family Court and to execute or amend their will, cannot be overlooked. ${ }^{92}$ There is some indication that a court will consider the testamentary intentions of the parties to the marriage and the potential for a property division under the Act to affect these intentions. The High Court in Stanford did not need to address this as a potentially significant factor in allowing the appeal. Nonetheless the issue of an early 'Inheritance Act application' was raised squarely in the case at first instance ${ }^{93}$ and reliance placed by the husband on the concerns expressed by Kay J in Sterling about the potential use of family law proceedings for this purpose. This issue was acknowledged by the Full Court in Stanford ${ }^{94}$ with the Court noting the following remarks of Kay J in Sterling: ${ }^{95}$

It is widely known that as the life expectancy of our community becomes greater, so does the incidence of dementia. The problem which presents itself in this case and in Jennings' case is likely to become more prevalent. When coupled with an increase in the incidence of remarriage and "blended families", the pressures to ensure that each party to the marriage has an

$87 \quad$ Ibid, [38].

88 [2008] FMCAfam 1156.

89 Ibid, [78].

90 Ibid, [81].

91 Starkey (2009) 41 Fam LR 517, [13].

92 Arguably, it is less likely that an inheritance claim will be a motivating factor for a step-child to commence family court property proceedings on behalf of a parent who has lost capacity to do so if the step-child can bring an 'Inheritance Act claim' in their own right. This is possible now in Western Australia, for example, since amendments expanding the category of eligible claimants under the Family Provision Act 1972 (WA) s 7(1)(ea) came into effect (on 16 January 2013).

93 Re $S$ by her Case Guardian $R$ and $S$ by his Case Guardian $S$ [2010] FCWAM 26, [143].

94 (2011) 46 Fam LR 240, [115].

95 [2000] FamCA 1150, [26]. 
estate available to pass on to their descendants grows. The real protagonists in this type of litigation may often not be the parties to the marriage but their heirs and successors. An issue clearly arises as whether it is appropriate that the Family Law Act be utilised as the means by which the competing claims of the next generation should be aired.

In Stanford, the Magistrate found all the parties and their witnesses to be honest, and there is nothing in the Full Court's decision that suggests that this was not a finding that was open on the facts. For this reason, although the Full Court found her Honour to have erred in determining that the wife had financial needs that should be met by making a property settlement order, the Court does not suggest that the application was not properly brought.

It remains an open question in future cases what weight, if any, a court will place on the fact of an intact marriage in an application made by a case guardian in similar circumstances. The question also remains open as to how the court will deal with the potential for the financial interests of adult children (or other beneficiaries) managing a case to be prioritised over the non-financial interests of their parent (including an ongoing relationship with their spouse or an ability to continue living in the matrimonial home) ${ }^{96}$ Is there a point at which a conflict in priorities or self-interest is a basis for declining to make orders? These questions arise aside from questions about who should be appointed case guardian where the proposed case guardian may have a financial interest in the outcome.

Kay J in Sterling appears to suggest that the court could exercise its discretion not to make an order if:

[T] he motive behind the proceedings was merely to benefit others without any clear benefit to the incompetent spouse (such as proceedings commenced after the spouse had given instructions when competent but the commencement of the proceedings had been delayed for negotiations or preparation of documents).$^{97}$

His Honour goes on to say that once it has been determined to make an order, s 79(4)(e) considerations set out in s 75(2) may so favour the competent spouse that the justice of the situation requires a major shift away from a contribution based division. This appears to be consistent with what the Full Court says in Stanford in allowing the appeal although it did not need to decide the matter.

In Sterling, Kay J distinguished the situation where a court will consider it appropriate to make an order from the situation where a court might say that "no order should be made because the real recipient of the benefit of the order will be someone other than the incompetent spouse'. ${ }^{98}$ It is not clear that a decision to not make orders on this basis alone remains open after Stanford. The court would need to apply this reasoning to conclude that it would not be just and equitable to make

96 See Olivia Rundle, 'Recent Cases' (2012) 2(2) Family Law Review 118, 122.

97 [2000] FamCA 1150, [46].

98 Ibid, [47]. 
any order at all. It remains to be seen whether there is scope to have regard to this consideration pursuant to s 75(2)(o), or more generally, in determining pursuant to $\mathrm{s} 79(2)$, whether it is just and equitable to make an order under s 79(1).

\section{E The Legal Position of Parties to a De Facto Relationship}

Stanford and previous decisions of the Family Court concerned married couples. The legal situation is different where the application for property orders is brought on behalf of a party to a de facto relationship. The Act relies, for constitutional validity, on powers referred by the States to the Commonwealth Parliament. The referral of power by the States to the Commonwealth over the financial matters of parties to a de facto relationship is confined to parties whose de facto relationship has broken down. Therefore the Family Court only has jurisdiction to make an order for maintenance or an order altering the interests of the parties to the de facto relationship in their property after the breakdown of the de facto relationship. ${ }^{99}$ As a consequence, the question whether a court will make orders for the alteration of interests of property and maintenance when a marital relationship has not broken down will only arise in a case concerning a married couple.

The constitutional limitation on the power of the Family Court of Australia to make financial orders with respect to parties to a de facto relationship that has not broken down does not apply in Western Australia. The constitutional power to make orders with respect to the property of parties to a de facto relationship living in Western Australia resides in the State Parliament. Jurisdiction over the financial affairs of parties to a de facto relationship is conferred on the Family Court of Western Australia. The Family Court Act 1997 (WA) provides, however, (similarly to the Act) that '[a] de facto partner whose de facto relationship has ended' may apply for an order under the applicable provisions. ${ }^{100}$ Although the section does not provide that an application can only apply in these circumstances, it is clear that it is intended to be interpreted in this way. ${ }^{101}$ The difference between Western Australia and the rest of Australia is that the Western Australian Parliament has the constitutional power to confer on the Family Court of Western Australia jurisdiction to make property orders for parties to a de facto relationship that has not ended. Although it is unlikely, if that were to occur, the fact that the relationship is intact would be a relevant factor to the decision by the court, whether it was a just and

$99 \quad$ Family Law Act 1975 (Cth) s 90SE (maintenance), s 90SM (alteration of property interests).

100 Family Court Act 1997 (WA) s 205ZB(1).

101 The Second Reading speech by the Attorney-General Mr McGinty makes clear that the Family Court Amendment Bill 2001 (WA) which introduced de facto financial proceedings in WA was intended to apply in the event of a breakdown of a de facto relationship. Western Australia, Parliamentary Debates, Legislative Assembly, 29 August 2001, 3290b (Jim McGinty, Attorney-General). 
equitable requirement as required by s 205ZG(3), to make an orders for the alteration of property under the Family Court Act 1997 (WA).

Other questions arise when a third party is seeking financial orders on behalf of a party to a de facto relationship who has lost legal capacity to make decisions about ending the relationship, about management of their financial matters, and about care and accommodation needs. Unlike marriage and divorce, the question whether a de facto relationship exists is a question of fact. Although on a practical level a court may require a party to a de facto relationship to show separation has occurred using the same test of intention, action and communication as is required to make out the ground for divorce under s 48 of the Act, the court's jurisdiction depends on the continued existence of the relationship rather than evidence of separation. ${ }^{102}$

\section{Implications for Involuntarily Separated Couples of Family Court Financial Proceedings}

The legal position for married couples who are separated by the loss of decision-making capacity of one or both parties or physical separation, or both, can be summarised as follows:

\section{A Physical Separation Does Not Equate to Breakdown of a Marriage}

Stanford confirms that involuntary physical separation is a relevant consideration in property and maintenance proceedings but it is not necessary for parties to have separated for the court to have jurisdiction to make orders. This contrasts to an application for divorce: to obtain a divorce order it must be proved that the parties have separated as evidence that the marriage has broken down irretrievably. ${ }^{103}$ Although the Family Court has power to make property orders when the parties have not separated, it must be satisfied that it would be just and equitable to do so. For family lawyers advising their clients after Stanford, the central inquiry will be to identify the factors that make it 'just and equitable' to make orders for a property settlement.

\section{B The Family Court Can Make Property \\ Orders Notwithstanding That One of the Parties to the Proceedings Has Died}

This confirms precious decisions of the High Court as to the effect of s 79(8) of the Act. ${ }^{104}$ In making orders the court must be satisfied that the

102 Lisa Young, Geoffrey Monahan, Adiva Sifris and Robyn Carroll, Family Law in Australia (8th ed, 2013) [6.120].

103 Family Law Act 1975 (Cth) s 48(2).

104 Fisher v Fisher (1986) 161 CLR 438. 
terms of this subsection are met. In particular, that it would have been just and equitable to make an order had the party not died and that it is still appropriate to make an order.

\section{The Court Can Make Orders With Respect to the Property of Parties to a Marriage That Has Not Broken Down}

It is not necessary for a marriage to have broken down before orders can be made by the Family Court for maintenance or in property proceedings. The Act confers power on the Family Court to make orders for the alteration of property interests between people who are married. The power conferred by the Act on the Family Court is based on marriage, not separation or divorce.

\section{Family Court Property Orders for Couples Who Have Not Separated Can be Expected to be Uncommon but May Be Necessary in Some Circumstances}

For most elderly parties to an intact marriage the decision in Stanford will have little or no significance. Where it will impact is in cases where a party to a marriage has lost their decision-making capacity on matters such as forming the intention to end their marriage, deciding where to live and with whom, and making financial decisions. In these circumstances they become vulnerable to financial and emotional abuse. This can occur in at least two circumstances.

The first situation in which an elderly party to an intact marriage is vulnerable to abuse is when a third party to the marriage takes it upon himself or herself to physically separate that person from their spouse or de facto partner. An example would be where an adult child of a first marriage decides to relocate their parent to another State or Territory to live with them and in doing so effects a physical separation of the parties to a second marriage. This may amount to 'emotional abuse' of the parties to the marriage. (This situation is even more likely to arise where the incapable person is in a de facto or close personal relationship than where they are married because it may be factually uncertain whether the relationship satisfies the definition of being a 'de facto relationship' as defined in s $4 \mathrm{AA}(1)$ of the Act.) In this type of 'forced separation', as in the involuntary separation by ill health seen in Stanford, the question whether orders for financial support will be made in the Family Court will depend on the financial circumstances of the couple after the 'separation' rather than on whether the parties' marriage has broken down.

The second situation is where a party to marriage has financial needs that cannot be met out of their own property and their spouse has property that they are not willing to use to support their incapacitated spouse. This could be described as financial 'neglect' and a form of elder abuse. In this situation a person other than the spouse is able to apply to be appointed as decision-maker for the incapable spouse under legislation providing for 
the appointment of a guardian or administrator in the relevant State or Territory where the couple live and to be appointed as case guardian by the Family Court in order to bring property or maintenance proceedings. Neither the incapable person nor their appointed guardian or case guardian is able to effect a marital separation for the purposes of divorce but, as we have seen, the decision in Stanford leaves open the possibility that an application for financial support through orders for maintenance and the alteration of property interests can be made in these circumstances. It is apparent from the decision of the High Court that the potential for a maintenance order during the lifetime of the party to the marriage to meet their financial needs will make an order of this type more likely than an order that finally alters the property interests of the parties. Where the separation of the parties is not voluntary, the bare fact of separation does not demonstrate that they have any good reason to 'alter the property interests that lie behind whatever common use they may have made of assets when they able to and did live together'. ${ }^{105}$

\section{E Parties to Marriage Can Exclude Family Court's Jurisdiction to Make Property Orders by Financial Agreement that Complies with Act}

Parties to a marriage who wish to ensure that their separate entitlements to property are not alterable pursuant to the terms of s 79 of the Act (and to fulfil their succession expectations) may do so by entering into a financial agreement pursuant to Pt VIIIA of that Act.

This is a way for couples to exclude the court from making orders in respect of their property, and it may become increasingly popular amongst couples who marry for a second or subsequent time and wish to ensure that their property is passed on to their children or other chosen successors according to their will. A combination of reluctance by couples entering into marriage, and cautious advice by family lawyers in view of the possibility that an agreement might not be enforceable, is likely to result in a low uptake of this possibility. It is to be hoped that recent decisions of the Family Court ${ }^{106}$ will bring greater certainty as to how the requirements of the Act are to be satisfied, and in turn greater confidence amongst family lawyers and their clients to make binding agreements about their individually and jointly owned property. The federal government introduced a Bill on 25 November 2015 that includes measures designed to address uncertainties in the current financial agreement provisions in the Act. ${ }^{107}$ Based on experience to date it remains unlikely that many elderly couples

105 Stanford v Stanford (2012) 247 CLR 108, [44].

106 Hoult and Hoult (2013) 50 Fam LR 260; Wallace v Stelzer (2013) 51 Fam LR 115; Weldon and Asher [2014] FCWA 11. For comment on the position after Hoult, see Martin Bartfeld QC, 'Hoult and Hoult: The Full Court Explains Financial Agreements - Again' (2013) 23(3) Australian Family Lawyer 1.

107 Family Law Amendment (Financial Agreements and Other Measures) Bill 2015. 
will make binding financial agreements in anticipation of or during their marriage, for a whole range of reasons.

\section{CONCLUSION}

Before the decision in Stanford, there was no doubt that a party to a marriage with decision-making capacity could make an application for maintenance or property orders against a spouse who had lost decisionmaking capacity. It was also clear that the Family Court could determine an application for maintenance or property orders on behalf of an incapable person who was a party to a marriage, whether or not the marriage had broken down before the proceedings were commenced. Doubts had been raised, however, about whether the Court should exercise the power to make property orders where a couple had not separated voluntarily. The High Court confirmed in Stanford that the Family Court has power to make orders with respect to the property of parties to an intact marriage but that this power is only exercisable if a court is satisfied that it would be just and equitable to do so. The ongoing task for family lawyers and the Family Court is to clarify the circumstances in which this broadly framed statutory requirement will and will not be satisfied. While recent decisions of the Family Court already provide some guidance, ${ }^{108}$ none of these have been cases in which the parties to the marriage (or de facto relationship) have not separated.

The need for an order in these circumstances will most likely arise when the parties to the marriage are living separately on a permanent basis. There is a real possibility that a stranger to the marriage, for example a child of one or both of the couple, will be able to bring an application on behalf of a party to the marriage that ultimately may benefit them personally as a beneficiary of the incapable person. Clearly one of the challenges for a person appointed to make financial decisions for an incapable person is to balance the financial and non-financial interests of that person, including the benefits of an ongoing and harmonious relationship with their spouse and other family members, against the financial benefits of the financial proceedings. In this way there is potential for the interests of the decision-maker to compete and even conflict with the person they represent. These are issues that need to be carefully considered in choosing who to appoint as an administrator or a guardian. One would also hope this would be taken into account in the appointment of a case guardian for Family Court proceedings.

Marriage does not alter legal and equitable interests in marital property. A third party to a marriage may believe that a party to the marriage who has contributed to the marriage, but has lost their capacity to negotiate with their spouse or to effect a separation, should be entitled

108 Watson (on behalf of estate of Watson) $v$ Ling (2013) 49 Fam LR 303 (de facto relationship); Bevan v Bevan (2013) 49 Fam LR 387; Granath and Granat [2014] FCWA 49; Fielding $v$ Nicol [2014] FCWA 77 (de facto relationship). Note, all of these are cases where the parties had separated. 
to access the property of their spouse through Family Court proceedings. This belief, however, does not reflect the legal reality that there must be reasons other than this to alter the existing legal and equitable interests of the parties in their property. The Act does not allow any order to be made unless, as stated in s 79(2), the court is satisfied that in all the circumstances, it is just and equitable to make the order'.

The circumstances in which it will be just and equitable to make an order for the alteration of property where parties have involuntarily separated are not circumscribed by the decision in Stanford. It will be a challenge to decide what orders a court should make in the face of an application for final property orders where financial need is established. In the end, parties to a marriage who wish to ensure that their separate entitlements to property are not alterable pursuant to the terms of $\mathrm{s} 79$ of the Act (and to fulfil their succession expectations) may do so by entering into a financial agreement pursuant to Pt VIIIA of that Act.

If, as has been the experience to date, most couples will not take advantage of the financial agreement provisions, the possibility of a Family Court making a property order can only be avoided by financial planning that takes into account the possibility that one or both of the parties to a marriage may need to access their property to meet their accommodation and health care needs. The reality for all couples, whether they separate voluntarily or not, is that the family home may need to be sold to secure suitable residential care. If an order of the Family Court is necessary to effect the sale, parties to an intact marriage will be in the unenviable position of having the Court decide for them how to share their property during their marriage.

This article has considered the circumstances in which this situation can arise, the advantages and disadvantages accompanying the Family Court's involvement and ways that the parties can avoid this situation arising. It concludes that there is a delicate balance to be struck between preserving the institution of marriage and protecting a party to a marriage who has lost the capacity to make decisions about their marriage and their financial affairs, and that the decision of the High Court of Australia in Stanford will enable this delicate balance to be achieved in individual cases. 